\title{
Isolation, bioprospecting and diversity of salt-tolerant bacteria associated with sugarcane in soils of Pernambuco, Brazil ${ }^{1}$
}

\author{
Maria C. B. S. Leite ${ }^{2}$, Andreza R. B. de Farias ${ }^{3}$, Fernando J. Freire 4 , \\ Fernando D. Andreote ${ }^{5}$, Júlia Kuklinsky-Sobral ${ }^{6} \&$ Maria B. G. S. Freire ${ }^{7}$ \\ ${ }^{1}$ Trabalho selecionado do II INOVAGRI International Meeting, realizado de 13 a 16 de abril de 2014, Fortaleza - CE, Brasil. Extraído da Dissertação de Mestrado da primeira autora \\ ${ }^{2}$ UAG/UFRPE. Garanhuns, PE. E-mail: camilabarross@gmail.com (Autor correspondente) \\ ${ }^{3}$ UAG/UFRPE. Garanhuns, PE. E-mail: andreza_quel@yahoo.com.br \\ ${ }^{4}$ UFRPE. Recife, PE. Bolsista PQ/CNPq. E-mail: f.freire@depa.ufrpe.br \\ ${ }^{5}$ ESALQ/USP. Piracicaba, SP. E-mail: fdandreo@gmail.com \\ ${ }^{6}$ UAG/UFRPE. Garanhuns, PE. E-mail: jksobral@yahoo.com.br \\ ${ }^{7}$ UFRPE. Recife, PE. Bolsista PQ/CNPq. E-mail: betania@depa.ufrpe.br
}

\section{Key words:}

endophytic

genetic variability

plant growth promotion

\begin{abstract}
A B S T R A C T
\section{Isolamento, bioprospecção e diversidade de bactérias \\ tolerantes à salinidade associadas a cana-de-açúcar em solos de Pernambuco, Brasil}

The selection of salinity tolerant bacteria may provide greater promotion of plant growth in soils with salt stress. This study aimed to isolate and select bacterial isolates of sugarcane, tolerant to salinity and plant growth promoters, and assess genetic diversity. To do so, endophytic root and rhizosphere of sugarcane, were isolated in culture medium with and without $\mathrm{NaCl}$. The bacterial population density, the potential for biological nitrogen fixation (BNF), production of indole acetic acid (IAA), inorganic phosphate solubilization and quorum sensing molecule production were evaluated. Furthermore, the genetic diversity was assessed by Denaturing Gradient Gel Electrophoresis (DGGE) of nifH. Salinity tolerance tests were also conducted. There was no statistical difference in population density. As for the potential for BNF, IAA production, phosphate solubilization and quorum sensing molecule production, there was a high percentage of positive isolates. In the technique of DGGE nifH, the dendrogram showed high genetic variability. So there was the selection of bacteria that can contribute to the better development of sugarcane in saline soils.

\section{Palavras-chave:}

endofítica

promoção de crescimento vegetal

variabilidade genética

\section{INTRODUCTION}

The sugarcane (Saccharum spp.) is an important crop in Brazil and besides the corn in the United States, is responsible for most of the ethanol produced in the world (Waclawovsky et al., 2010). The sugarcane is an exigent crop about the fertility and appears sensitive to limiting aspects such as soil salinity. According to Freire \& Freire (2007) saline soils are characterized by the accumulation of salts in horizons or layers near the surface and excess salts, next to the roots causes toxicity to plants and decreases the absorption of water.

Despite being an area under humid climate, problems of salt accumulation in soils in this area of Pernambuco has been observed due to the application of vinasse. When applied to the soil, vinasse causes a series of changes in its chemical and physical characteristics, especially in $\mathrm{pH}$, cation exchange capacity (CEC), organic carbon, water retention, electrical conductivity, porosity, and also affecting population and 
activity of microorganisms in the soil (España-Gamboa et al., 2011).

Like plants, bacteria that are in association with sugarcane, exhibit variation in salinity tolerance and its characteristics which promote plant growth, such as nitrogen fixation, production of phytohormones, solubilization inorganic phosphate, among others (Nobrega et al., 2004) may be affected. This situation can be mitigated by using bacterial strains tolerant to salt stress. These bacteria are known as halotolerant, not require salt for metabolism but tolerate salts at different concentrations (Mishra et al., 2011).

In this context, the objective of this study was to isolate and to identify bacterial isolates of sugarcane, and salt-tolerant plant growth promoters, which may contribute to the better development of this species in sugarcane producing regions of Pernambuco and in parts of semiarid region in which there are salt affected soils and where the sugarcane is not grown, as well as evaluating the genetic diversity independent culture by DGGE of nifH. The study also aimed evaluating the influence of salinity, using sodium chloride $(\mathrm{NaCl})$, on bacterial growth, the production of indole acetic acid and the phosphate solubilization in vitro.

\section{Material AND Methods}

Soil samples adhered to the outer surface of the root, being considered here the rhizosphere soil and root plants of RB 863129 variety of sugarcane were collected in the second half of 2011 (sugarcane ratoon with 10 months of cultivation), in three areas of the power plant Petribu S/A, Lagoa de Itaenga (Pernambuco, Brazil). The first area with vinasse application for two years ( $\mathrm{V}-2$ years), as fertilizer, the second with vinasse application for four years (V-4 years), as fertilizer and the third without vinasse application (No V) with three replications in each of the areas.

Soil samples were analysed for chemical characterization, soil $\mathrm{pH}$ and electrical conductivity of the saturation extract (EC), levels of available $\mathrm{P}, \mathrm{K}^{+}, \mathrm{Na}^{+}, \mathrm{Ca}^{2+}, \mathrm{Mg}^{2+}, \mathrm{Al}^{3+}, \mathrm{H}+\mathrm{Al}$, the sum of bases (SB), the cation exchange capacity (CEC) and base saturation $(\mathrm{V})$ were determined by the methods described in EMBRAPA (1997) (Table 1). After soil collection, $5 \mathrm{~g}$ of rhizospheric soil were placed under stirring (with Phosphate Buffered Saline) at $120 \mathrm{rpm}$, at room temperature for $40 \mathrm{~min}$ (Araújo et al., 2010).

The roots of plants of sugarcane were washed in running water to remove residues of dust and soil, passed through a surface disinfection process, this process, along with the isolation methodology followed recommendations of Mendes et al. (2007) and Araújo et al. (2010). After this process, the material was transferred to $50 \mathrm{~mL}$ tubes and incubated under agitation $(120 \mathrm{rpm})$ at room temperature for $40 \mathrm{~min}$. Then, serial dilutions of appropriate solutions were inoculated in triplicate in Petri dishes containing culture medium TSA (Triptone Soy Agar), plus 0 or $5 \% \mathrm{NaCl}$ and incubated at $28^{\circ} \mathrm{C}$ for 10 days. Purification of the colonies was performed by exhaustion amid TSA. Isolated colonies were stored for future testing.

The selection of nitrogen-fixing bacteria potential was performed by inoculation of isolated colonies in semisolid medium NFb-free nitrogen source, according Döbereiner et al. (1995), and incubated at $28^{\circ} \mathrm{C}$ for 10 days. The experiments were performed in duplicates and the positive result was characterized by forming a horizontal halo within the culture medium, and subcultured for three consecutive times.

The selection of inorganic phosphate solubilizing bacteria followed the methodology described by Silva et al. (2012). After this procedure, positive colonies were inoculated into culture medium containing solid insoluble phosphate, according to methodology previously described, plus four concentrations of sodium chloride $(\mathrm{NaCl}): 0,2.5,5.0$ and $7.5 \%$, or $0,34.31,68.63$ and $102.94 \mathrm{dS} \mathrm{m}^{-1}$ (Moradi et al., 2011). After inoculation, the plates were incubated at $28{ }^{\circ} \mathrm{C}$ for $72 \mathrm{~h}$, the bacterial growth and the phosphate solubilization were evaluated. The test was performed in triplicate. The diameter of the colonies and the halos of solubilization was measured, from these measurements were obtained from each SI.

The selection of acid producing bacteria indole acetic acid (IAA) was performed by the colorimetric and specific method which characterizes the specific production of phytohormone (Crozier et al., 1988). The methodology used was described by Pereira et al. (2012). As positive control strain EN303 (Pseudomonas oryzihabitans), endophytic bacteria from soybean producing auxin was used, solubilizing inorganic phosphate and $\mathrm{N}_{2}$ fixation (Kuklinsky-Sobral et al., 2004). Then positive colonies were inoculated onto TSA broth supplemented with L-tryptophan ( $5 \mathrm{mM}$ ), following the same methodology, plus the same four concentrations of sodium chloride ( $\mathrm{NaCl}$ ) (Moradi et al., 2011). After inoculation, the tubes were incubated at $28^{\circ} \mathrm{C}$ with agitation $(120 \mathrm{rpm})$. The readings of bacterial growth (optical density, OD) were taken at $0,24,48$ and 72 hours, in a spectrophotometer $(600$ $\mathrm{nm})$. The test was performed in triplicate.

To analyze the production of IAA, the same samples of the OD readings were used, they were evaluated in a

Table 1. Chemical characterization of soil samples collected in the three areas cultivated with sugarcane with and without vinasse

\begin{tabular}{|c|c|c|c|c|c|c|c|c|c|c|c|c|}
\hline \multirow{2}{*}{ Area } & \multirow{2}{*}{$\mathrm{pH}$} & \multirow{2}{*}{$\begin{array}{c}\text { EC } \\
\mathrm{dS} \mathrm{m}^{-1}\end{array}$} & \multirow{2}{*}{$\begin{array}{c}P \\
\mathrm{mg} \mathrm{kg}^{-1}\end{array}$} & $\mathbf{K}^{+}$ & $\mathrm{Na}^{+}$ & $\mathrm{Ca}^{2+}$ & $\mathrm{Mg}^{2+}$ & $\mathrm{Al}^{3+}$ & $\mathrm{H}+\mathrm{Al}$ & SB & CEC & V \\
\hline & & & & \multicolumn{8}{|c|}{$\mathrm{cmol}_{\mathrm{c}} \mathbf{k g}^{-1}$} & $\%$ \\
\hline No Va & 5,57 & 1,96 & 0,33 & 0,09 & 0,22 & 2,20 & 0,70 & 0,05 & 1,65 & 3,20 & 4,85 & 66,0 \\
\hline $\mathrm{V}-2$ anos $^{\mathrm{b}}$ & 6,00 & 0,95 & 7,33 & 0,35 & 0,22 & 2,80 & 1,20 & 0,05 & 2,31 & 4,57 & 6,88 & 66,4 \\
\hline V-4 anos ${ }^{c}$ & 5,88 & 1,14 & 3,00 & 0,50 & 0,30 & 4,70 & 2,50 & 0,05 & 3,63 & 8,00 & 11,63 & 68,8 \\
\hline
\end{tabular}

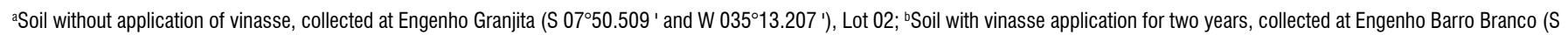
$07^{\circ} 55.065$ ' and W $035^{\circ} 14.825^{\prime}$ ), Lot 51 ; ' 'Soil with vinasse application for four years, collected at Engenho Barro Branco (S $07^{\circ} 55.292^{\prime}$ and W $\left.035^{\circ} 14.909^{\prime}\right)$, Lot 76 , all of power plant Petribu S/A, Lagoa de Itaenga (Pernambuco, Brazil). 
spectrophotometer, and the absorbance measurements at $530 \mathrm{~nm}$, at $0,24,48$ and 72 hours. The test was performed in triplicate.

Isolated colonies were inoculated in Petri dishes with LB medium (Luria-Bertani) supplemented with X-gal (5-bromo4-chloro-3-Indolyl-beta-D-galacto-pyranoside) $\left(10 \mathrm{mg} \mathrm{mL}^{-1}\right)$ entire surface. The bacteria Agrobacterium tumefaciens NTL4 (pZLR4) AHLs biosensor was also inoculated transversely and close to the isolates. According to the methodology described by Quecine (2010) after incubation at $28{ }^{\circ} \mathrm{C}$ for $48 \mathrm{~h}$, it can be observed, for the positive test, colonies of A. tumefaciens pigmented blue, indicating production of AHLs for isolated evaluated. The test was performed in duplicate.

The samples of plant roots and rhizosphere of sugarcane grown on different soils were used for extracting total DNA by means of 'Power Soil DNA kit' (MoBio; EUA), second manufacturer's recommendations. After extraction, the DNAs were referred to the Laboratory of Soil Microbiology, School of Agriculture Luiz of Queiroz, University of São Paulo (ESALQ/USP), and were amplified using the primers FGPH19 (5'-TACGGCAARGGTGGNATH-3') and PolR (5'-ATSGCCATCATYTCRCCG-3'), nifH according to the methodology of Andreote (2007).

A second amplification reaction was performed using the amplification products as a source of DNA, with primers PolFGC (5'-CGCCCGCCGCGCCCCGCGCCCGGCCCGCCGCC CCCGCCCCTGCGAYCCSAARGCBGACTC-3') and AQER (5'-ACGATGTAGATYTCCTG-3'), second methodology performed by Andreote (2007). All PCR products were verified on $1 \%$ agarose gel in TAE $1 \mathrm{X}$ to confirm amplification of the desired product. The final product of amplification was used for the analysis of DGGE (Denaturing Gradient Gel Electrophoresis) (Andreote, 2007).

The bands generated by amplification were converted into binary data and, with these, the construction of a spreadsheet, which was analysed using the software Past 1.90 (Hammer et al., 2001), using the algorithm UPGMA (Unweighted Pair-Group Method with Arithmetical Average) and applying the Jaccard coefficient to obtain the similarity matrix between the strains analyzed.

The chi-square $\left(\chi^{2}\right)$, with a probability of 0.05 was used to investigate the possible influence of the following treatments: rhizosphere and endophytic, application of vinasse or not, presence or absence of $\mathrm{NaCl}$, about bacterial expression of those characteristics. Results of the measurement of indole acetic acid and the Phosphate Solubilization Index were assessed by the Scott-Knott, with a probability of through the program SISVAR 5.3.

\section{Results AND Discussion}

During the insulation experiments, 102 bacterial isolates were obtained from the variety RB 863129 of sugarcane, after 10 months of growth in three areas of power plant Petribu, in Pernambuco. In total 41 were from the rhizosphere and 61 root endophytes, which were purified through TSA and appointed in UAGCV1 the UAGCV120. The isolates distribution as to the application of vinasse was: 39 from the area without application of vinasse, 35 from the application area for two years and 28 from the application area for four years. Of the 102 isolates, 48 were obtained in TSA medium with the addition of salt.

As the bacterial population density, it was observed that there was no statistical difference between the niches, rhizosphere and root endophytic; between treatments with and without application of vinasse, and with the presence or absence of salt. The values ranged from 6.42 the $8.59 \mathrm{CFU} \mathrm{g}^{-1}$ plant tissue or soil $\left(\mathrm{LOG}_{10}\right)$. It is extremely important to study the interaction bacteria/plant, because many factors can influence it, such as climate, treatment with pesticides, soil type, soil structure, stage of development of the host plant, among others (Berg \& Smalla, 2009). These factors influence the bacterial community of the plant, which may make it more diverse or dominant groups (Procópio et al., 2009).

It was observed that out of 102 isolates tested, $72.5 \%$ were positive for the potential of biological nitrogen fixation (BNF). Among the isolated positive, $66.22 \%$ are from the root (the analysis by the $\chi^{2}$ test revealed no influence of treatment) and $50 \%$ of the medium with added salt (analysis by $\chi^{2}$ test showed no influence of the treatments). The treatments without vinasse, with vinasse for two years and for four years obtained approximately, 42,30 and $28 \%$, respectively, of isolates positive for biological fixation. For the latter result, the analysis by the $\chi^{2}$ test showed no influence of the treatments. When comparing the distribution of positive isolates FBN, according to the presence of vinasse and the region of the plant, it was found that in all cases the isolated endophytic root stood out. This also occurred in the presence and absence of salt in the culture medium.

Due to the great importance of the sugarcane crop in Brazil, encouraging research has been high (Pereira et al., 2012), aiming to find an inoculant effective, since sugarcane removes large amounts of soil nitrogen.

In this study, $72.5 \%$ of isolates were potential atmospheric nitrogen fixers, proving the potential of these bacteria to crop management programs of sugarcane. It was observed that the largest number of fasteners is isolated endophytic root of sugarcane, either in the presence or absence of salt, such as the presence or absence of vinasse, probably due to this bacterial group may have an important role in this niche or have better conditions for colonization. This may occur by the interaction bacteria/plant, as this influences the characteristics of plant growth promotion (Kuklinsky-Sobral et al., 2004).

Of the 102 isolates analysed, 75.5\% were positive for the solubilization of inorganic phosphate, similar to the Lira-Cadete et al. (2012), where $75 \%$ of diazotrophs of sugarcane were positive for this feature. However, this result was lower than that presented by Santos et al. (2012), where the authors found that of the 30 diazotrophic bacteria associated with sugarcane ratoon plants, root endophytic and rhizosphere, $90 \%$ were able to solubilize inorganic phosphate in vitro.

Considering the niche source of bacterial isolates, $74 \%$ are root endophytic and $26 \%$ of the rhizosphere of sugarcane (the 
analysis by the $\chi^{2}$ test revealed no influence of treatment). In assessing the effects of the absence of vinasse and its application for two years and four years, a frequency of 35,36 and $29 \%$ was observed of the positive isolates of phosphate solubilization, respectively. Considering the presence of salt, $56.8 \%$ of positive isolates were obtained from culture medium with the addition of salt. For the latter, the analysis by the $\chi^{2}$ test showed no influence on treatments. As for FBN, comparing the distribution of positive isolates for solubilization of phosphate according to the presence of vinasse and the region of the plant, it is observed that in all cases the isolated endophytic root stood out. This also occurred in the presence and absence of salt in the culture medium.

Regarding the influence of salinity, 27 bacterial isolates were tested, positive for the four tests of plant growth promotion. No isolate was able to solubilize phosphate at concentrations of 5 and $7.5 \% \mathrm{NaCl}$ in the medium used, the results were presented only phosphate solubilization in the means with 0 and $2.5 \% \mathrm{NaCl}$. In these 27 isolates, 16 solubilized phosphate in the presence of $2.5 \% \mathrm{NaCl}$ (Figure 2) and it can be seen that, in general, the presence of salt decreased the solubilization index, in which only the isolated UAGCV77 no decrease was observed in the potential of solubilization in the presence of $2.5 \%$ salt (Figure 1 ).

It is noteworthy that, as for the BNF, the presence of vinasse and the presence of $\mathrm{NaCl}$ did not affect the results of phosphate solubilization. However, once again the recess excelled in all cases where the isolated root endophytic showed significantly greater percentage of phosphate solubilization. Demonstrating that this bacterial group may have an important role in this niche the host plant. This result is similar to Lira-Cadete et al. (2012), where the root endophytic isolates, stoodout this feature to promote plant growth.

Regarding SI, eight isolates had an index greater than two, which was the group with the higher rate. Santos et al. (2012) observed the isolates having reached index of 3.48. However, isolates of this study have shown as potential plant growth promoters, as presented SI satisfactory, in other words, greater than 2 (Lealem \& Gashe 1994).

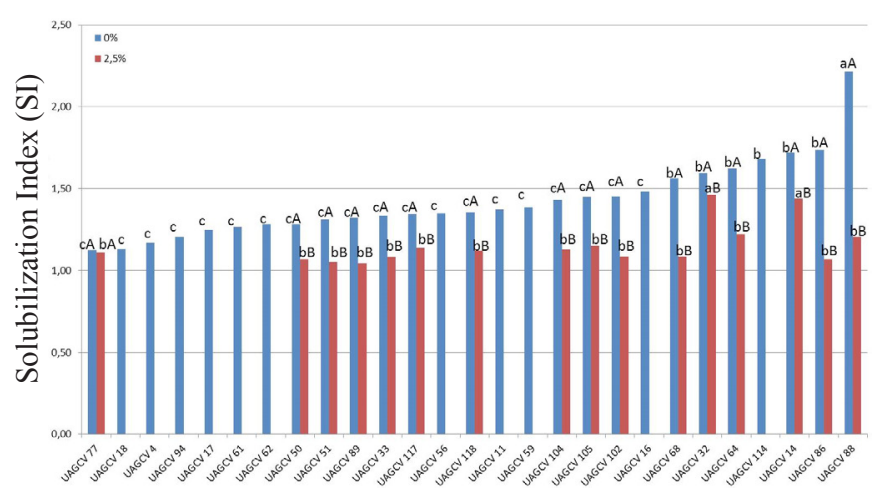

Different lowercase letters represent the means within each salinity ( 0 and $2.5 \%$ ) are statistically different. Different capital letters represent statistical difference by the Scott-Knott test at 0.05 probability level, between salinities for the same bacteria

Figure 1. Solubilization index of inorganic phosphate by rhizosphere and root endophytic bacteria, from sugarcane, after three days in medium rich in insoluble phosphate plus 0 and $2.5 \% \mathrm{NaCl}$
The presence of salt in the culture medium influenced negatively, since out of the 27 strains evaluated, only 16 were able to solubilize phosphate in vitro by the addition of $2.5 \%$ salt in the culture medium. A similar result was observed by Sadeghi et al. (2011), where isolated from Streptomyces decreased phosphate solubilization, when the salt concentration in the culture medium increased. Only isolate UAGCV77 showed no reduction in the potential for solubilization, suggesting that this isolate can be studied for use in crop management programs of sugarcane in saline soils.

Regarding the production of IAA $100 \%$ of the isolates were positive. Some isolates had very low production, the example of UAGCV7 with $1.45 \mu \mathrm{g} \mathrm{mL}^{-1}$; while others had high production, as the UAGCV117 with $162.23 \mu \mathrm{g} \mathrm{mL}^{-1}$.

With respect to salinity two isolates were evaluated, UAGCV16 and UAGCV68, selected after testing plant growth promotion. As can be seen in Figure 2A the isolate UAGCV16 was more sensitive to the presence of salt in the culture medium, with no growth at 5 and $7.5 \%$ salt while UAGCV68 showed growth in all salinities studied.

However, the growth of isolate UAGCV16 was significant reaching of 0.608 OD at $0 \%$ salt; while UAGCV68 reached only 0.227 . The latter isolate showed no statistical difference between growth at 0 and $2.5 \%$ salt in the culture medium. Both isolates tended to increase stability $72 \mathrm{~h}$.

With respect to the production of IAA, the influence of salt promoted similar results for both isolates (Figure 2B) as the salt concentration increases, production of IAA decreased. Despite the lower absolute growth, the isolated UAGCV68 showed higher production of IAA, reaching $157.27 \mathrm{mg} \mathrm{mL}^{-1}$. However, after 48 $\mathrm{h}$ in all salinity values the production dropped considerably. As for the isolated UAGCV16 the fall in production after $48 \mathrm{~h}$ was practically nil.

According to the results, it was also possible to observe the ability of the isolates to produce IAA, as the plant hormone production or plant growth regulators; it is another feature that few bacterial species when combined with the plant host express. Lima (2012), working with varieties of sugarcane ratoon phase, also observed that $100 \%$ of bacterial isolates evaluated had capacity to produce IAA in medium with addition of tryptophan. These results demonstrate that sugarcane is widely colonized by bacteria producing this phytohormone.

It is noteworthy that some isolates showed high production of IAA, as the isolated UAGCV117 with $162.23 \mu \mathrm{g} \mathrm{mL} \mathrm{m}^{-1}$. According to Hernandez-Rodriguez et al. (2010) about 29 $\mu \mathrm{g} \mathrm{mL} \mathrm{m}^{-1}$ of IAA were produced by isolates of Burkholderia cepacia in maize and rice seedlings, low value compared to the production of IAA isolates of the present study.

Regarding the influence of the salt, in a study by Campos et al. (2010) isolate from the root nodules and stem Discolobium spp. growth was evaluated at a concentration of $3 \%$ salt; while the present study, the isolate UAGCV16 managed to grow only in the maximum concentration of $2.5 \%$ salt, confirming that this has become more sensitive to salinity of the medium. UAGCV68 isolate grew in all concentrations studied, although the concentrations of 5 and $7.5 \%$ the growth was less, it 

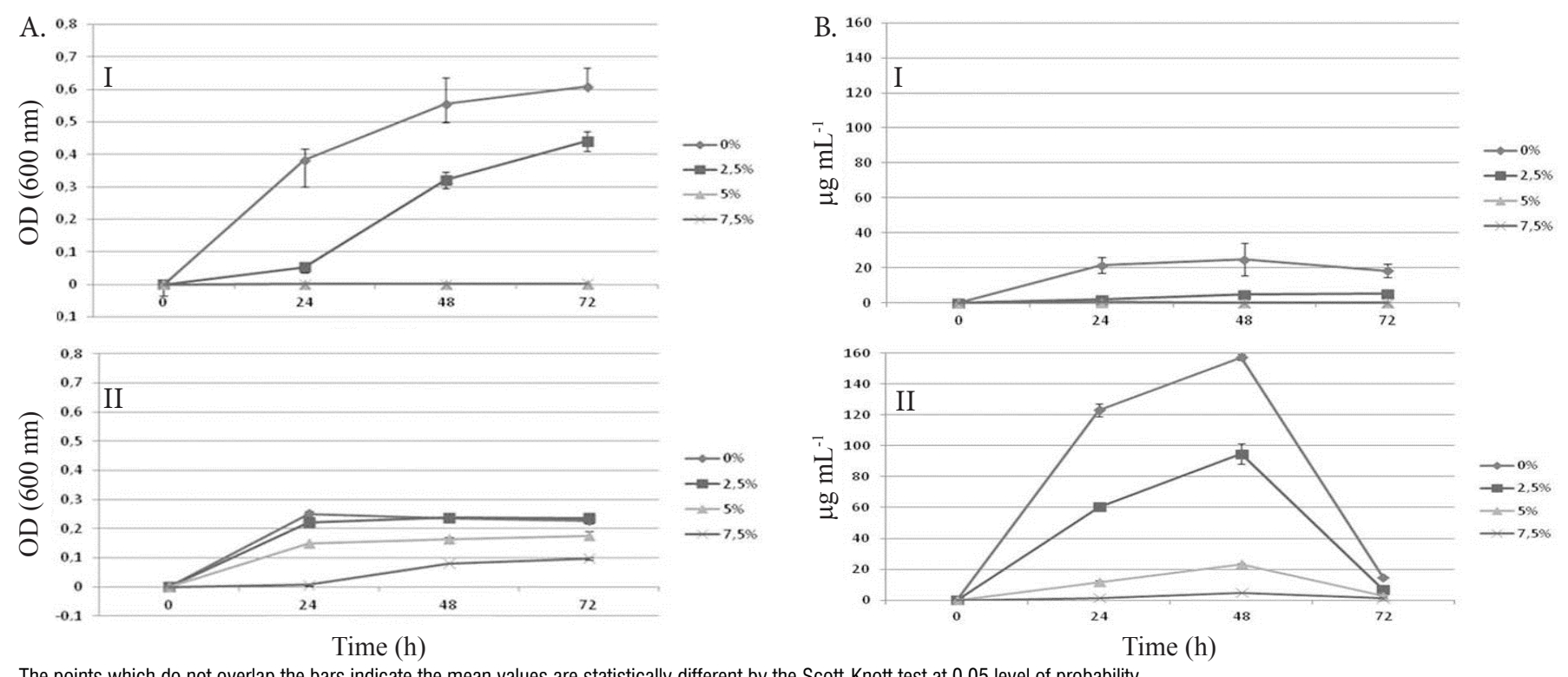

The points which do not overlap the bars indicate the mean values are statistically different by the Scott-Knott test at 0.05 level of probability

Figure 2. A - Growth curves (optical density - OD) of root endophytic bacteria, in liquid TSA supplemented with 0, 2.5, 5.0 and $7.5 \% \mathrm{NaCl}$. B - Curves indole acetic acid production by bacteria root endophytic in TSA broth supplemented with L-tryptophan and 0, 2.5, 5.0 and 7.5\% NaCl. I) Isolated UAGCV16; II) Isolated UAGCV68

demonstrates that this isolate has been derived from a culture medium with added salt presents more tolerant, since it went through a selection process. In the present study, the production of IAA was negatively influenced by the presence of salt; similar result was described by Pereira et al. (2012).

Of 102 strains tested, $49 \%$ were positive for the production of the quorum sensing molecule ( $\mathrm{N}$-acyl homoserine lactone, AHL), because the colonies of A. tumefaciens showed blue pigmentation. Of the positive isolates, $44 \%$ were from the rhizosphere and $56 \%$ of root endophytic plants sugarcane (the analysis by the $\chi^{2}$ test showed no influence of the treatments). Concerning the application of vinasse for four years, two years and the lack of implementation, respectively, 26, 26 and 48\% of positive isolates were obtained, in relation to this capacity. Regarding the presence of salt in the culture medium, $64 \%$ of positive isolates were from the medium without the addition of $\mathrm{NaCl}$. The analysis by the $\chi^{2}$ test revealed no influence of these treatments.

When the distribution of positive isolates for the production of AHL was compared according to the presence of vinasse and the region of the plant, it is noted that the rhizosphere isolates were prominent in the absence of vinasse, whereas the other treatments the isolated root endophytic had higher relative frequency. With regard to the presence and absence of salt in the culture medium, only the isolated endophytic distinguished. It is noteworthy that, out of the 102 isolates, 33 were positive for the four tests. In order to complement the selection of a bacterium with the potential to become an inoculant, production of quorum sensing molecule, AHL, becomes an ally. For biofilm formation a response to quorum sensing mechanism has been considered (Rumjanek et al., 2004), and the biofilm is a great ally of bacterial colonization (Liu et al., 2011). Thus, an inoculant which has some facility in colonizing the host plant is essential for the efficiency of the process.
Of the 102 isolates, $49 \%$ were positive for the production of quorum sensing molecule, percentage lower than that shown by Ravn et al. (2001), where, among 148 isolates the family Enterobacteriaceae $99 \%$ were producing molecules AHLs. However, the positive isolates have shown potential for use in the management of the sugarcane crop.

It is noteworthy that $48 \%$ of the positive isolates were from the area without application of vinasse, demonstrating that the bacterial population present in soil is more efficient for this feature, and that the isolates from the rhizosphere were also more efficient in this condition, reinforcing the bacterial population can change from one management to another. Furthermore, $64 \%$ was isolated in culture medium without the addition of $\mathrm{NaCl}$. This demonstrates the influence of the management and the presence of salt on a characteristic of plant growth promotion.

The isolates of this study were promising because 33 were positive for the four tests, with strong aspiring future programs of in vivo tests.

Analysis of bacterial diversity uncultivable by the DGGE technique, by nif $\mathrm{H}$, has observed high genetic variability, both in the community rhizospheric as root endophytic. Only two replicates of rhizosphere samples without the application of vinasse showed similarity above $70 \%$ (Figure 3 ), all other groups had low similarity, showing the diazotrophic bacterial diversity existing in plants of sugarcane, cultivated in different soils.

The result of this study demonstrates the diversity of the community in diazotrophic existing sugarcane grown in different soils. A similar result was obtained by Lima (2012), where there was high genetic variability of the diazotrophic bacterial community of the rhizosphere and root endophytic after 4 and 10 months of cultivation of sugarcane variety RB 


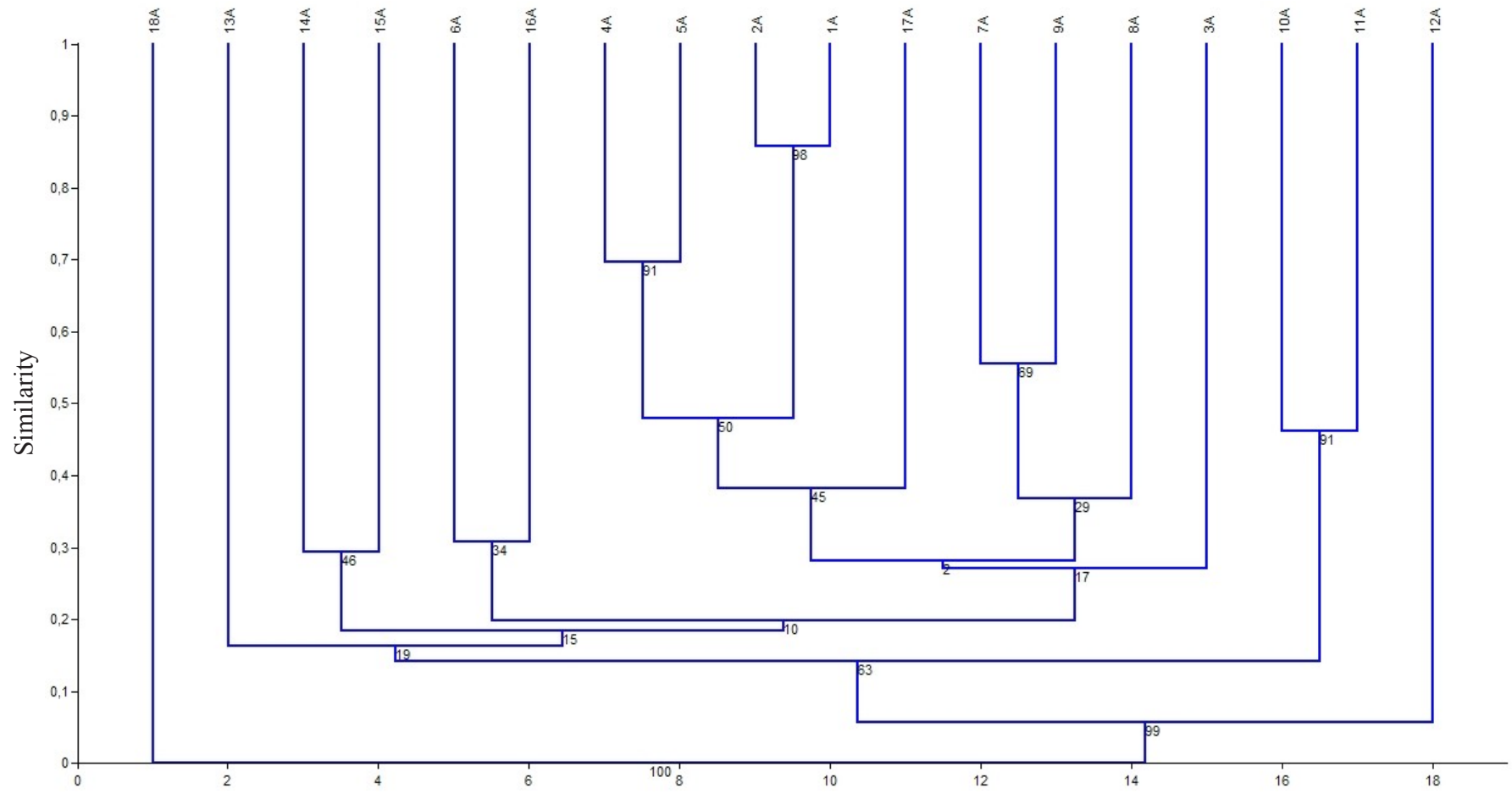

Legend: $1 \mathrm{~A}, 2 \mathrm{~A}$ e $3 \mathrm{~A}$, rhizosphere - without vinasse; $4 \mathrm{~A}, 5 \mathrm{~A}$ e $6 \mathrm{~A}$, rhizosphere - vinasse application during two years; $7 \mathrm{~A}, 8 \mathrm{~A}$ e $9 \mathrm{~A}$, rhizosphere - vinasse application during four years; $10 \mathrm{~A}$, $11 \mathrm{~A}$ e $12 \mathrm{~A}$, root endophytic - without vinasse application; 13A, 14A e 15A, root endophytic - vinasse application during two years; 16A, 17A e 18A, root endophytic - vinasse application during four years

Figure 3. Similarity dendrogram constructed based on the sequences of bands obtained by primers FGPH19, PolR, PolF-GC and AQUER, for the nifH, by DGGE technique through the Jaccard coefficient and by the method of UPMGA with bootstrap 1000 times. The numbers at the nodes in question indicate the percentage of times that the group remained on consensus

867515 ratoon plants. According to Berg \& Smalla (2009) both the type of soil and the cultivated species, may be the factors that would influence the bacterial community. Thus, it is evident that the soil management data for the application of vinasse, in this study, may have been crucial to the genetic diversity observed.

\section{Conclusions}

1. The endophytic isolates were more efficient in the potential to fix nitrogen, solubilize phosphate, produce IAA and AHL quorum sensing molecule.

2. There was high diversity of the gene nifH of bacterial community both rhizosphere and endophytic root.

3. Bacterial growth and characteristics of plant growth promotion may be negatively affected by the presence of salt in the culture medium.

\section{Literature Cited}

Andreote, F. D. Determinant factors in the composition of bacterial communities with plants associated. Piracicaba: ESALQ/USP, 2007. 201p. PhD Thesis

Araújo, W. L.; Lacava, P. T.; Marcon, J.; Lima, A. O. S.; Kuklinsky-Sobral, J.; Pizzirani-Kleiner, A. A.; Azevedo, J. L. Practice guide: Isolation and characterization of endophytic microorganisms. Piracicaba: CALO, 2010. 167p.
Berg, G.; Smalla, K. Plant species and soil type cooperatively shape the structure and function of microbial communities in the rhizosphere. FEMS Microbiology Ecology, v. 68, p.113, 2009.

Campos, L. L.; Martins, M. E.; Elias Neto, N.; Loureiro, M. F. Physiologic characterization of rhizobia isolates of root and stem nodules of Discolobium spp. Scientia Agraria Paranaensis, v.9, p.75-84, 2010.

Crozier, A.; Arruda, P.; Jasmim, J. M.; Monteiro, A. M.; Sandberg, G. Analysis of indole-3-acetic acid and related indoles in culture medium from Azospirillum lipoferum and Azospirillum brasiliense. Applied and Environmental Microbiology, v.54, p.2833-2837, 1988.

Döbereiner, J.; Baldani, V. L. D.; Baldani, J. I. Como isolar e identificar bactérias diazotróficas de plantas nãoleguminosas. Brasília: Embraoa SPI, Itaguaí, Embrapa CNPAB, 1995. 60p.

EMBRAPA - Empresa Brasileira de Pesquisa Agropecuária. Manual de métodos de análise de solo. Rio de Janeiro: Centro Nacional de Pesquisa de Solos, 1997. 212p.

España-Gamboa, E.; Mijangos-Cortes, J.; Barahona-Perez, L.; Dominguez-Maldonado, J.; Hernández-Zarate, G.; AlzateGaviria, L. Vinasses: characterization and treatments. Waste Management \& Research, v.29, p.1235-1250, 2011.

Freire, M. B. G. S.; Freire, F. J. Fertilidade do solo e seu manejo em solos afetados por sais. In: Fertilidade do Solo. Novais, R. F.; Alvarez V., V. H.; Barros, N. F.; Fontes, R. L. F.; Cantarutti, R. B.; Neves, J. C. L. (ed.). Viçosa: Sociedade Brasileira de Ciência do Solo, 2007. p.929-954. 
Hammer, O.; Harper, D. A. T.; Ryan, P. D. PAST: Paleontological statistics software package for education and data analysis. Palaentologia Eletronica, v.4, p.1.9. 2001.

Hernández-Rodríguez, A.; Heydrich-Pérez, M.; Diallo, B.; Jaziri, M. E.; Vandeputte, O. M. Cell-free culture medium of Burkholderia cepacia improves seed germination and seedling growth in maize (Zea mays) and rice (Oryza sativa). Plant Growth Regulation, v.60, p.191-197, 2010.

Kuklinsky-Sobral, J.; Araújo, W. L.; Mendes, R.; Geraldi, I. O.; Pizzirani-Kleiner, A. A.; Azevedo, J. L. Isolation and characterization of soybean-associated bacteria and their potential for plant growth promotion. Environmental Microbiology, v.6, p.1244-1251, 2004.

Lealem, F; Gashe, B. A. Amylase production by a gram-positive bacterium isolated from fermenting tef (Eraglostis tef). Journal of Applied Bacteriology, v.77, p.348-352, 1994.

Lima, D. R. M. Nitrogen fixing bacteria associated with plants of sugarcane cultivated in Pernambuco. Recife: UFRPE, 2012. 110p. Master's Dissertation

Lira-Cadete, L.; Farias, A. R. B.; Ramos, A. P. S.; Costa, D. P.; Freire, F. J.; Kuklinsky-Sobral, J. Genetic variability of sugarcane-associated diazotrophic bacteria capable of inorganic phosphate solubilizing. Bioscience Journal, v.28, p.122-129, 2012.

Liu, X.; Jia, J.; Popat, R.; Ortori, C. A.; Li, J.; Diggle, S. P.; Gao, K. Cámara, M. Characterization of two quorum sensing systems in the endophytic Serratia plymuthica strain G3: differential control of motility and biofilm formation according to lifestyle. BMC Microbiology, v.11, p.1-12, 2011.

Mendes, R.; Pizzirani-Kleiner, A. A.; Araujo, W. L.; Raaijmakers, J. M. Diversity of cultivated endophytic bacteria from sugarcane: genetic and biochemical characterization of Burkholderia cepacia complex isolates. Applied and Environmental Microbiology, v.73, p.7259-7267, 2007.

Mishra, R. R.; Prajapati, S.; Das, J.; Dangar, T. K.; Das, N.; Thatoi, $\mathrm{H}$. Reduction of selenite to red elemental selenium by moderately halotolerant Bacillus megaterium strains isolated from Bhitarkanika mangrove soil and characterization of reduced product. Chemosphere, v.84, p.1231-1237, 2011.

Moradi, A.; Tahmourespour, A.; Hoodaji, M.; Khorsandi, F. Effect of salinity on free living-diazotroph and total bacterial populations of two saline soils. African Journal of Microbiology Research, v.5, p.144-148, 2011.
Nóbrega, R. S. A.; Motta, J. S.; Lacerda, A. M.; Moreira, F. M. S. Tolerância de bactérias diazotróficas simbióticas à salinidade in vitro. Ciência e Agrotecnologia, v.28, p.899905, 2004.

Pereira, A. P. A.; Barros, M. C. S.; Oliveira, J. R. S.; Ramos, A. P. S.; Freire, M. B. G. S.; Freire, F. J.; Kuklinsky-Sobral, J. Salinity influence on the growth and production of indole acetic acid by endophytic Burkholderia spp. from sugarcane. Bioscience Journal, v.28, p.112-121, 2012.

Procópio, R. E. L.; Araújo, W. L.; Maccheroni Jr., W.; Azevedo, J. L. Characterization of an endophytic bacterial community associated with Eucalyptus spp. Genetics and Molecular Research, v.8, p.1408-1422, 2009.

Quecine, M. C. Biotechnological aspects of the interaction between bacteria and sugarcane (Saccharum sp. L.). Piracicaba: ESALQ/USP, 2010. 196p. PhD Thesis

Ravn, L.; Christensen, A. B.; Molin, S.; Givskov, M.; Gram, L. Methods for detecting acylated homoserine lactones produced by Gram-negative bacteria and their application in studies of AHL-production kinetics. Journal of Microbiological Methods, v.44, p.239-251, 2001.

Rumjanek, N. G.; Fonseca, M. C. C.; Xavier, G. R. Quorum sensing em sistemas agrícolas. Biotecnologia, Ciência \& Desenvolvimento, v.33, p.35-50, 2004.

Sadeghi, A.; Karimi, E.; Dahaji, P. A.; Javid, M. G.; Dalvand, Y.; Askari, H. Plant growth promoting activity of an auxin and siderophore producing isolate of Streptomyces under saline soil conditions. World Journal of Microbiology \& Biotechnology, v.28, p.1503-1509, 2012.

Santos, I. B.; Lima, D. R. M.; Barbosa, J. G.; Oliveira, J. T. C.; Freire, F. J.; Kuklinsky-Sobral, J. Diazotrophic bacteria associated to roots of sugarcane: Inorganic phosphate solubilization and the salinity tolerance. Bioscience Journal, v.28, p.142-149, 2012.

Silva, M. O.; Freire, F. J.; Lira-Junior, M. A.; Kuklinsky-Sobral, J.; Costa, D. P.; Lira-Cadete, L. Isolation and identification of endophytic and epiphiytic bacteria in sugarcane in areas with and without termiticide. Revista Brasileira de Ciência do Solo, v.36, p.1113-1121, 2012.

Waclawovsky, A. J.; Sato, P. M.; Lembke, C. G.; Moore, P. H.; Souza, G. M. Sugarcane for bioenergy production: an assessment of yield and regulation of sucrose content. Plant Biotechnology Journal, v.8, p.263-276, 2010. 